\title{
STUDIES ON THE SELECTED PROPERTIES OF C45 STEEL ELEMENTS SURFACE LAYER AFTER LASER CUTTING, FINISHING MILLING AND BURNISHING
}

\author{
Agnieszka Skoczylas ${ }^{1}, K^{\prime} a z i m i e r z ~ Z a l e s k i{ }^{1}$ \\ 1 Faculty of Mechanical Engineering, Lublin University of Technology, Nadbystrzycka 36, 20-618 Lublin, Poland, \\ e-mail: a.skoczylas@pollub.pl, k.zaleski@pollub.pl
}

Received: 2016.07.14 Accepted: 2016.10.08 Published: 2016.12.01

\begin{abstract}
The article presents the results of studies on surface roughness and microhardness of C45 steel elements after laser cutting, and then finishing milling or burnishing. The aim of milling was to get rid of the characteristic "striae" after laser cutting and to improve geometric accuracy. Burnishing caused hardening of C45 steel elements' surface layer after laser cutting and improvement in surface roughness. In order to measure surface roughness, the Hommel-Etamic device T8000 RC120 - 400 with software was used. The roughness parameters that were analyzed in the article were: amplitude parameters, height parameters and Abbott-Firestone curve. The microhardness measurements were made with the use of Vicker's hardness test with a weight of $50 \mathrm{~g}$. As a result of the finishing of the surface after cutting, a decrease in surface roughness and improvements in functional qualities were noticed. In addition, hardening of the edgeside area also occurred, which is an advantageous phenomenon.
\end{abstract}

Keywords: laser cutting, finishing milling, burnishing.

\section{INTRODUCTION}

Due to its numerous advantages and a wide range of applications, laser cutting is more and more often used as a method of material division in industrial conditions.

The use of a coherent laser beam to cutting affects the geometric structure, microstructure, geometric accuracy and residual stresses. The constraints that relate to the use of the semi-finished product in the consecutive production process also result from some discrepancies on the cut elements' surface and edges [22] and the lack of the outline's perpendicularity to the surface of the cut plate [1].

Stereometric features of the laser-cut objects' surface layer result from the overlap of thermic and hydrodynamic processes [12]. The characteristic striae appear on the cut surface, which indicates that the material escapes from the cut- ting kerf $[9,3]$. Their presence is caused by oscillation of the laser head, laser power fluctuation, gas flow fluctuation and hydrodynamic flow of molten metal [6].

During laser cutting, some intense chemical reactions occur. The heat coming from the molten metal penetrates to cold areas surrounding the cutting kerf, which causes structural alternations close to the cutting kerf. This, in turn, causes increase in hardness [9]. Microcracks often appear on the cut plates surface and, when it comes to carbon steel, the surface oxidation occurs $[5,7]$.

During laser cutting, material becomes intensively heated, and then cooled very quickly with the use of the associated gas [18]. Molten material solidifies in unstable conditions, what results in the residual tensile stresses formation [5].

The occurrence of some undesirable effects on the laser cut elements, surface and some adverse surface layer features of the objects repre- 
Table 1. Percentage chemical composition and mechanical properties of C45 steel

\begin{tabular}{|c|c|c|c|c|c|c|c|c|}
\hline \multicolumn{8}{|c|}{ Chemical composition (average), [\%] } \\
\hline $\mathbf{C}$ & $\mathbf{M n}$ & $\mathbf{S i}$ & $\mathbf{P}$ & $\mathbf{S}$ & $\mathbf{C r}$ & $\mathbf{N i}$ & $\mathbf{M o}$ & $\mathbf{F e}$ \\
\hline 0,48 & 0,74 & 0,36 & 0,011 & 0,01 & 0,09 & 0,02 & 0,002 & rest \\
\hline \multicolumn{3}{|c|}{ Yield strength (min.) } & \multicolumn{3}{c|}{$\mathrm{Re}=430 \mathrm{MPa}=740 \mathrm{MPa}$} \\
\hline & Tensile strength (min.) & \multicolumn{3}{c|}{$250 \mathrm{HB}$} \\
\hline
\end{tabular}

sent strong indicators for the necessity of aftermachining of those elements.

Many studies show the research on the use of burnishing to rebuild stereometric and physical properties of the surface layer after electron - discharge machining [11] and laser hardening [13].

Burnishing is also used as an after-machining process and it is aimed at improving the surface layer's properties of the burnished objects. After burnishing, the decrease in surface roughness [4, $8]$ and the increase bearing ratio $[4,20]$ may occur. Some methods of burnishing enable shaping of the lubricating microgrooves on the burnished surface, which increases the surface's resistance to abrasive wear $[2,15]$. Burnishing may also be used as a method of machining that makes it possible to improve the adhesive properties of the surface [14].

An important result after burnishing is the improvement in the physical properties of surface layer. Study conducted with the use of positron annihilation method showed that burnishing causes the change in concentration of crystal lattice defects, which results in formation of compressive stresses on the surface layer [21]. One of the most important results of the change in the surface layer of the burnished objects is the increase in the resistance to fatigue wear $[19,16]$. Another positive result of burnishing, apart from the improvement in the surface layer features, is rounding of edges of the machined object [10].

Taking into consideration beneficial effects of burnishing, it was considered relevant to analyze the possibilities of using burnishing as a method of after-machining after laser cutting.

The aim of the research was to assess the influence of the chosen methods of after-machining, i.e. milling and burnishing, on the chosen surface layer properties of the laser-cut objects.

\section{METHODOLOGY}

In the research the samples each measuring $5 \times 8 \times 100 \mathrm{~mm}$ and made of non-alloy C45 steel, whose chemical composition and properties were presented in table 1, were used. This type of steel is widely used in mechanical engineering industry. It is used in production of moderately loaded machine elements, such as: spindles, shafts, axes, unhardened gear wheels, discs, levers, wheel hubs. The samples were made with the use of the laser cutting system LASER Amada $3000 \mathrm{~W}$ with standard parameters.

Peripheral milling process was conducted with the use of Sandvik double-bit flycutters of the diameter of $20 \mathrm{~mm}$ with insert 215880 APKT10 covered with TiN coat, and for the following technological parameters: $a_{p}=0,12 \mathrm{~mm}$, $v_{c}=102 \mathrm{~m} / \mathrm{min}, \mathrm{f}_{\mathrm{z}}=0,067 \mathrm{~mm} /$ tooth. The milling process was conducted on vertical machining center FV-580a. The depth of cut $a_{p}$ was selected so that during the milling process only the layer that was hardened during the laser cut process was removed.

Burnishing was conducted on the turning lathe C11/MB. A burnisher consisting of a set exerting feed force and a burnishing element, which was a Silicon Nitride $\left(\mathrm{Si}_{3} \mathrm{~N}_{4}\right) 8 \mathrm{~mm}$ diameter $\left(\mathrm{d}_{\mathrm{N}}\right.$ $=8 \mathrm{~mm}$ ) ball (see Figure 1), was used as a tool. Silicon Nitride shows weak adhesive interaction with steel.

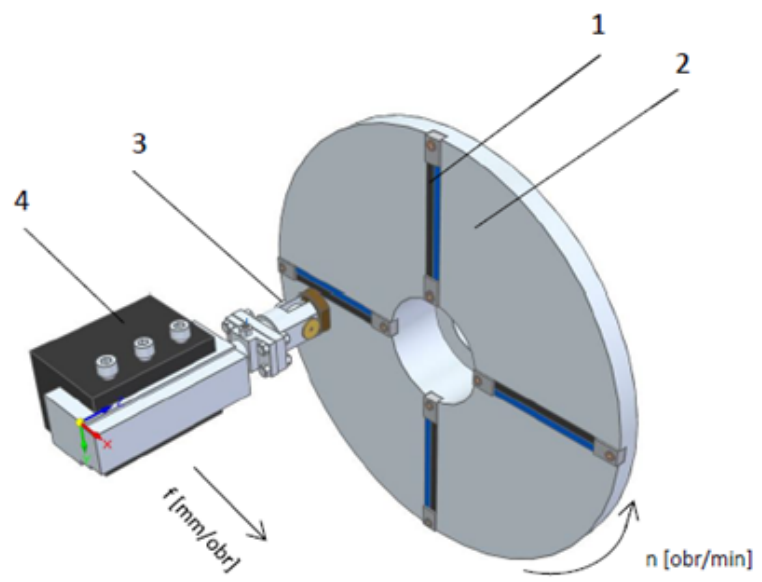

Fig. 1. Schema of the process burnishing: 1 - sample, 2 - holder, 3 - burnishing tool, 4 - tool post 
During the machining process, the samples 1 were fixed in a special disc-shaped handle 2 with four rows for flat samples of maximum width of $15 \mathrm{~mm}$. During the process of burnishing, the disc was performing rotary motion, and, in the same time, it was pressing the burnishing ball at constant force $\mathrm{F}$ against a machining object. Figure 1 depicts kinematics of burnishing. The machining process was conducted for the following parameters: burnishing feed $\mathrm{f}=0,05 \mathrm{~mm} / \mathrm{rev}$, burnishing force $\mathrm{F}=720 \mathrm{~N}$, burnishing speed $v_{N}=24 \mathrm{~m} /$ min, ball diameter $\mathrm{d}_{\mathrm{N}}=8 \mathrm{~mm}$.

Surface roughness measurements were performed with the use of T8000 RC120-400 appliance by Hommel-Etamic, which enables setting the amplitude and height parameters, bearing ratio and Abbott-Firestone curve parameters. The following parameters were determined: Ra- arithmetic mean of the roughness profile ordinates, Rz- the highest height of roughness profile and Abbott-Firestone curve parameters, $\mathrm{Rk}$ - roughness core depth, Rpk- reduced elevation height, Rvk - reduced valley depth. Bearing ratio Rmr was determined at the reference level $\mathrm{c}=1 \mu \mathrm{m}$ below zero values. The zero value was set at $5 \%$ distance from the highest height of the whole roughness profile height. Setting the carrier length coefficient of the profile this way enables to reduce the influence of the extreme heights on the results of the measurement of bearing ratio of surface roughness [17].

Microhardness measurements were performed using Vicker's method with the use of microhardness tester LM 700AT by Leco on perpendicular microsections and microindenter weighing $50 \mathrm{~g}$.

\section{RESULTS}

The results of the study show that the conducted machining processes resulted in stereometric and physical changes in the surface layer after laser cutting.

Figures 2 and 3 depict the measurements of surface roughness with relation to the conducted machining process. According to the data found in literature [6], the surface after laser cutting is characterized by two zones of differentiated roughness. Ra, Rz and Abbott-Firestone curve parameters are twice as high in the laser beam output zone than in the laser beam input zone. Burnishing that was conducted after laser cutting results in triple decrease in the amplitude and height parameters with relation to the laser cut surface. In the same time, the improvement in Rpk and Rk parameters occurs.

The milling process causes the removal of the characteristic striated structure, which, in turn, causes almost total elimination of laser beam input and output zones. Ra and Rz roughness parameters values, in relation to the laser cut surface, are about ten times lower. The changes also occur in the Rk parameters, which describe functional surface behaviour. Rpk parameter was about seven times lower for the input zone and about thirteen times lower for the output zone. It

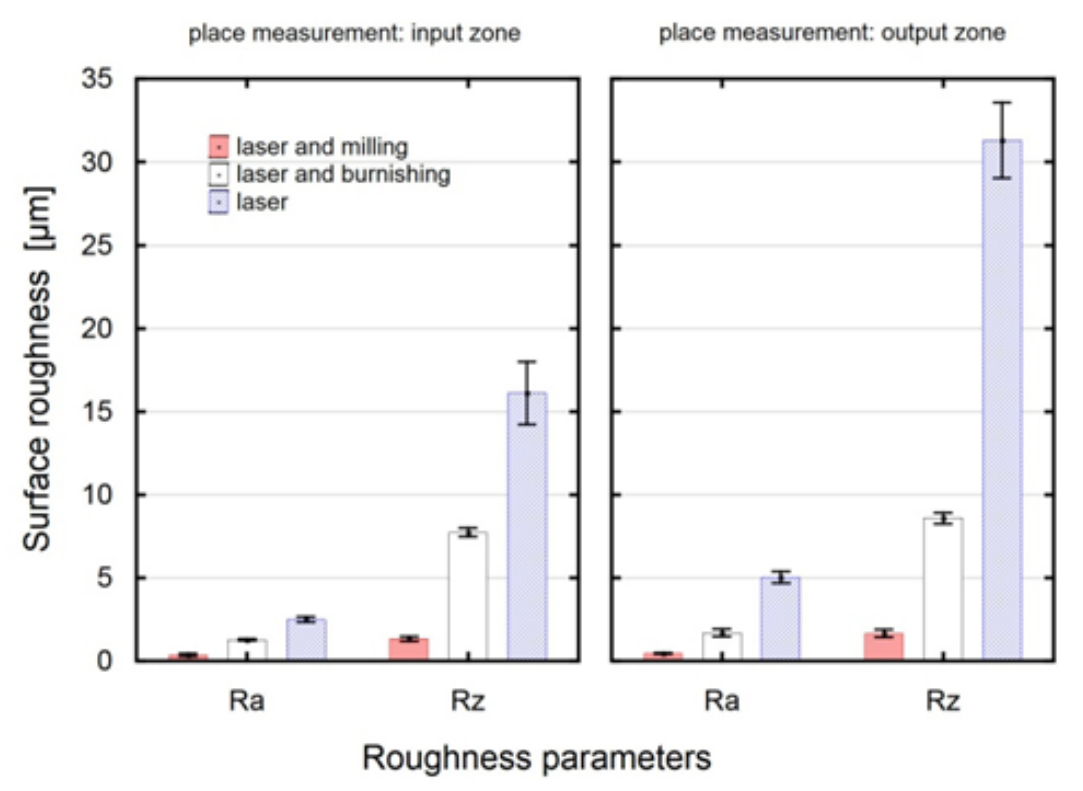

Fig. 2. Effect of treatment onto surface roughness parameters $\mathrm{Ra}$ and $\mathrm{Rz}$ 


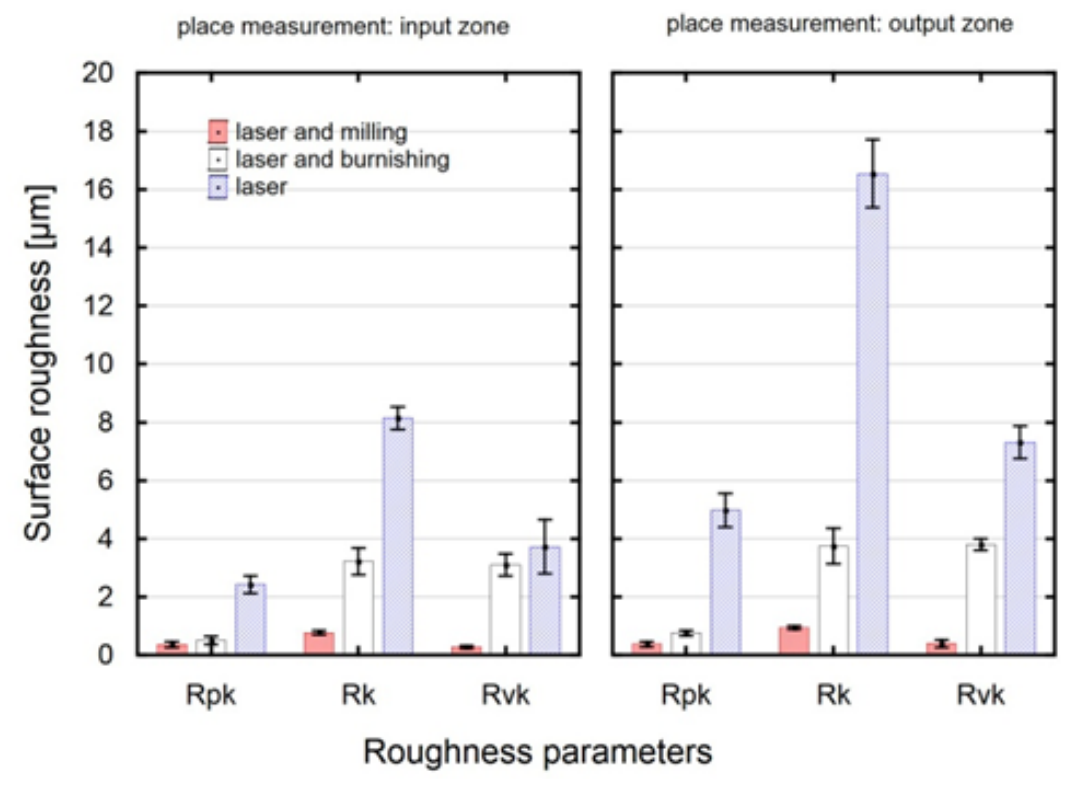

Fig. 3. Effect of treatment onto Abbott - Firestone curve parameters

means that the surfaces after the milling process will be marked by lesser wear in movable contact of two elements. The confirmation of this regularity is the increase in the bearing ratio of the surface roughness profile (Figure 4). As a result of finishing milling and burnishing processes, the Rvk parameter's value decreases. It means that the conducted machining causes the decrease in retention capacity of the lubricant.

Abbott-Firestone curve after laser cutting should be qualified as a degressive-progressive curve (Figure 5a). It is characterized by a wide angle of inclination. The surface described by this type of curve has "sharp" vertices of microinequalities and low bearing ratio (Figure 4). The profile of such surface is called a "narrow middle" curve [17]. It means that the laser cut surface is characterized by low abrasive wear resistance. After finishing milling, Abbott-Firestone curve is still a steep curve (Figure 5c). However, it is characterized by high bearing ratio for the input zone $\operatorname{Rmr}(1)=75,68 \% \pm 6,5 \%$. It is connected with the removal of the striated structure, which has numerous heights and depths. The process of burnishing causes the flattening of micro-inequalities vertices, Abbott-Firestone curve becomes a pro-

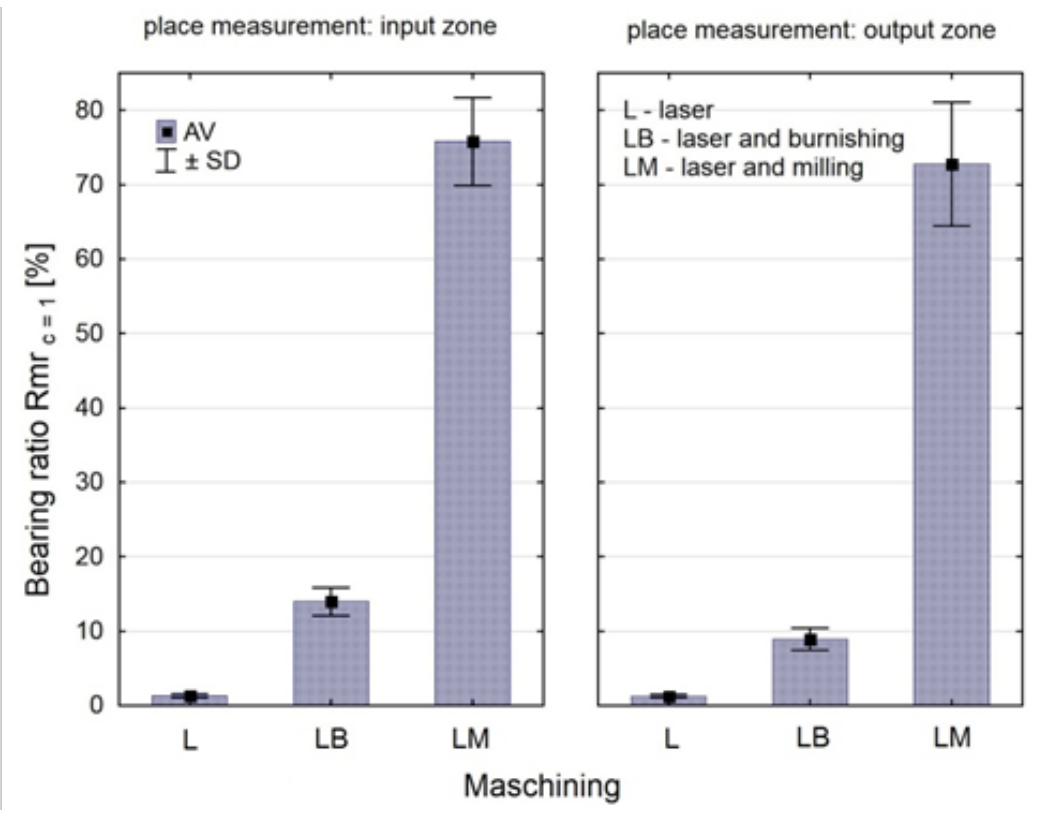

Fig. 4. Effect of treatment onto bearing ratio 

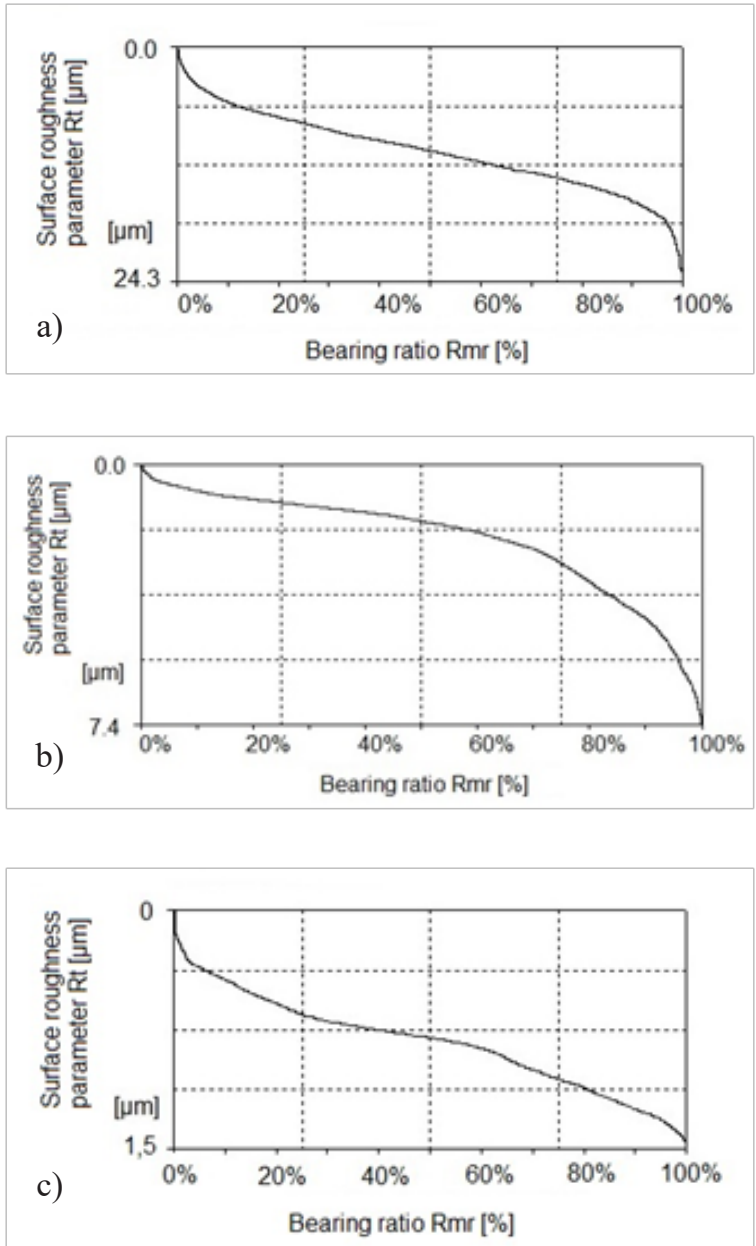

Fig. 5. Abbott - Firestone'a curve after: a) laser cutting, b) laser cuttig and burnishing, c) laser cutting and milling

gressive curve, which signifies the increase in resistance against abrasion (Figure $5 b$ ). This curve should be qualified as a "wide middle" curve.

During the performed machining processes, some changes in the edgeside area occur (Figure 6). The heat transported to the material during the process of laser cutting causes hardening of the area near to the edges of the cut, which in turn causes changes in structure and increase in microhardness. The width of the heat-affected zone (HAZ) is about $0,3 \mathrm{~mm}$. As a result of laser cutting, microhardness of surface layer in the area of the edges of the cut triples, and together with the increase in the distance from surface it decreases to the microhardness of the core. Burnishing causes the increase in dislocation density, what in turn leads to hardening of the surface layer. The increase in hardness is about $7 \%$, and thickness of the hardened layer is about $55 \mu \mathrm{m}$. During finishing milling

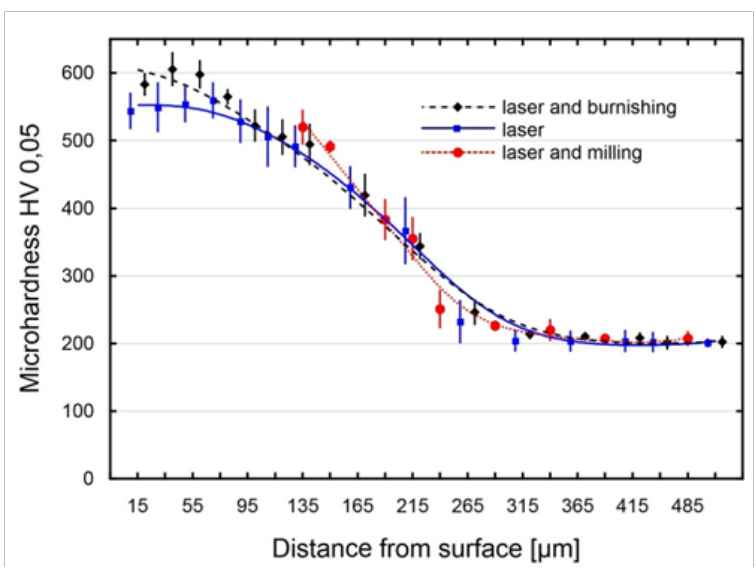

Fig. 6. Microhardness distribution of $\mathrm{C} 45$ surface layer after laser cutting, laser cutting and burnishing and laser cutting and milling

of the laser cut objects, a part of surface layer with the highest rate of microhardness is being removed. However, the very process of milling contributes to hardening of a small area very close to the edge. It is caused by mechanical interaction of cutting edges.

\section{CONCLUSIONS}

In this study the effects of the type of an aftermachining process upon the chosen surface layer of C45 steel after laser cutting were examined. The following conclusions sum up the results of the performed studies:

1. Burnishing of the surface after laser cutting enables to improve the roughness parameters $\mathrm{Ra}, \mathrm{Rz}, \mathrm{Rpk}, \mathrm{Rk}$. In the same time, hardening of the edgeside area occurs, which is an advantegous phenomenon.

2. The conducted after-machining processes of the surface after laser cutting cause the decrease in the height of the surface roughness, which in turn leads to the increase bearing ratio the roughness profile and the improvement in performance level.

3. The conducted finishing milling process of the surface after laser cutting eliminates zones of the differentiated roughness. In consequence of the performed machining process, the surface layer with the highest microhardness rate is removed, and also the thickness of the hardened layer is decreased. 


\section{REFERENCES}

1. Czupryn M., Szul T., Wpływ wybranych parametrów cięcia laserowego na jego wynik. Przegląd Spawalnictwa, 10, 2004, 9-12.

2. Galda L., Dzierwa A., Sep J., Pawlus P., The effect of oil pockets shape and distribution on seizure resistance in lubricated sliding. Tribology Letters, 37(2), 2010, 301-311.

3. Ghany K. A., Newishy M.: Cutting of $1.2 \mathrm{~mm}$ thick austenitic stainless steel sheet using pulsed and CW Nd: YAG laser. Journal of Materials Processing Technology, 168, 2005, 438-447.

4. Grzesik W., Zak K.,Prazmowski M., Surface integrity of hard turned parts modified by ball burnishing. Journal of Machine Engineering, 12(1), 2012, $18-27$.

5. Iordanova I., Antonov V., Gurkovsky S., Changes of microstructure and mechanical properties of cold- rolled low carbon steel due do its surface treatment by Nd: glass pulsed laser. Surface \& Coatings Technology, 153, 2002,267-276.

6. Kannatey-Asibu E., Jr., Principles of laser materials processing. John Wiley \& Sons, New Jersey, 2009.

7. Keles O., Oner U., A study of laser cutting process: influence of laser power and cutting speed on cut quality. Lasers in Engineering, 20, 2010, 319-327.

8. Kulakowska A., Kukielka L., Kukielka K., Malag L., Patyk R., Bohdal L., Possibility of steering of products surface layer properties in burnishing rolling process. Applied Mechanics and Materials, Vol. 474, 2014, 442-447.

9. Leszczynska-Madej B., Richert M., Sak T., Effect of unconventional methods of cutting on microstructure, topography and microhardness changes in steel. Metallurgy and Foundry Engineering, 38(2), 2012, 109-115.

10. Matuszak J., Zaleski K., Edge states after wire burnishing of magnesium alloys. Aircraft Engineering and Aerospace Technology, 86(4), 2014, 328-335.

11. Nowicki B., Podolak-Lejtas A., Investigations of the effect of combined EDM machining with burnishing process on the condition of the surface layer. Advances in Manufacturing Science and Tech- nology, 32(4), 2008, 5-17.

12. Powell J., Laser Cutting. Springer Verlag, London, 1993.

13. Radziejewska J., Laserowa modyfikacja właściwości warstwy wierzchniej wspomagana nagniataniem. Instytut Podstawowych Problemów Techniki PAN, Warszawa, 2011.

14. Rudawska A., Selected aspects of the effect of mechanical treatment on surface roughness and adhesive joint strength of steel sheets. International Journal of Adhesion \& Adhesives, Vol. 50, 2014, 235-243.

15. Sep J., Pawlus P., Galda L., The effect of helical groove geometry on journal abrasive wear. Archives of Civil and Mechanical Engineering, 13(2), 2013, 150-157.

16. Sledz M., Stachowicz F., Zielecki W., The effect of shot peening on the fatigue strength of steel sheets. Kovove Materialy - Metallic Materials, 53(2), 2015, 91-95.

17. Wieczorowski M., Cellary A., Chajda J., Przewodnik po pomiarach nierówności powierzchni czyli o chropowatości i nie tylko. Zakład PoligraficznoWydawniczy M-Druk, Poznań, 2003.

18. Yilbas B. S., Arif A. F. M., Abdul Aleem B. J, Laser cutting of sharp edge: Thermal stress analysis. Optics and Lasers in Engineering, 48, 2010, 10-19.

19. Zaleski K., Wpływ dynamicznego nagniatania rozproszonego na trwałość zmęczeniową elementów ze stopu tytanu Ti-6Al-4V. Eksploatacja i Niezawodność - Maintenance and Reliability, 4, 2009, 64-71.

20. Zaleski K., Skoczylas A., Effect of vibration shot peening parameters upon shapes of bearing curves of alloy steel surface. Advances in Science and Technology Research Journal, 9(25), 2015, 20-26.

21. Zaleski R., Zaleski K., Gorgol M., Wiertel M., Positron annihilation study of aluminum, titanium, and iron alloys surface after shot peening. Applied Physics A-Materials Science \& Processing, 120(2), 2015, 551-559.

22. PN-EN ISO 12584: 2004. Niezgodności w procesach cięcia płomieniowego tlenowo-gazowego, cięcia wiązką laserową i cięcia plazmowego. Terminologia. 